Article

\title{
Examining the Impact of Different DEM Sources and Geomorphology on Flash Flood Analysis in Hyper-Arid Deserts
}

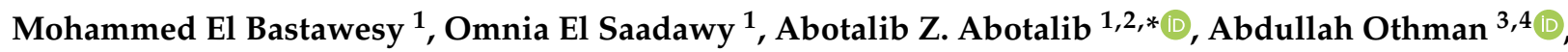 \\ Maysa Taha ${ }^{5}$ and Ahmed Gaber ${ }^{6}$
}

1 Division of Geological Applications and Mineral Resources, National Authority of Remote Sensing and Space Sciences, Cairo 11765, Egypt; m.elbastawesy@narss.sci.eg (M.E.B.); omnia.elsaadawy@narss.sci.eg (O.E.S.)

2 Viterbi School of Engineering, University of Southern California, Los Angeles, CA 98009, USA

3 Department of Environmental Engineering, Umm Al-Qura University, Makkah 21955, Saudi Arabia; agothman@uqu.edu.sa

4 Natural Hazards Research Unit, Department of Environmental and Health Research, Umm Al-Qura University, Makkah 21955, Saudi Arabia

5 Department of Geology, Helwan University, Cairo 11795, Egypt; maysanabeh@science.helwan.edu.eg

6 Department of Geology, Port Said University, Port Said 42511, Egypt; gaber@sci.psu.edu.eg

* Correspondence: afarag@usc.edu; Tel.: +20-12692678640

check for updates

Citation: El Bastawesy, M.; El Saadawy, O.; Abotalib, A.Z.; Othman, A.; Taha, M.; Gaber, A. Examining the Impact of Different DEM Sources and Geomorphology on Flash Flood Analysis in Hyper-Arid Deserts. ISPRS Int. J. Geo-Inf. 2021, 10, 431. https://doi.org/10.3390/ijgi10070431

Academic Editors: Paolo Paron and Wolfgang Kainz

Received: 5 April 2021

Accepted: 22 June 2021

Published: 24 June 2021

Publisher's Note: MDPI stays neutral with regard to jurisdictional claims in published maps and institutional affiliations.

Copyright: (c) 2021 by the authors. Licensee MDPI, Basel, Switzerland. This article is an open access article distributed under the terms and conditions of the Creative Commons Attribution (CC BY) license (https:// creativecommons.org/licenses/by/ $4.0 /)$.

\begin{abstract}
Digital elevation models (DEMs) are the cornerstone for hydrological and geomorphological modeling. Herein, two Nile-tributary catchments (Wadi Al Rishrash and Wadi Atfeh) in Egypt are selected to examine the contribution of different DEMs to the accuracy of hydrological and geomorphological analyses in the hyper-arid Sahara. DEMs sources include: Advanced Land Observing Satellite-1 (ALOS) Phased Array type L-band Synthetic Aperture Radar (PALSAR) (12.5 m resolution), ALOS World 3D with $30 \mathrm{~m}$ resolution (AW3D30), Advanced Spaceborne Thermal Emission and Reflection Radiometer (ASTER DEM with 30 m resolution) and the Shuttle Radar Topography Mission (SRTM with 30 and $90 \mathrm{~m}$ resolution), in addition to topographic map-derived DEM (90 m resolution). Using a hypothetical uniformly-distributed $10 \mathrm{~mm}$ rainfall event, the estimated parameters, including: flow duration, time to peak and peak discharge rates, are almost similar for the different DEMs and thus technical aspects related to sources and resolutions of the datasets impose insignificant control on quantitative flash-flood analyses. Conversely, variations in geological and geomorphological characteristics of the catchments show more significant control on the hydrograph magnitudes as indicated by the different parameters of the two catchments. These findings indicate that understanding the geological and hydrological evolution of the catchment is essential for integrated management strategies of floods especially in the Saharan-Arabian deserts and in similar conditions of hyper-aridity and scarce in situ data worldwide.
\end{abstract}

Keywords: DEM; Eastern Desert of Egypt; data sources; flash floods; geomorphology

\section{Introduction}

Dryland hydrological modelling usually incorporates multiple data sources, processing algorithms and field measurements to estimate quantitative parameters, which are being determined according to the identified sets of objectives. Overall, the depth distributions and patterns of flash floods currently receive a great deal of attention, due to the notable increase in the frequency and magnitude of flash-flood events, and the developed negative socio-economic consequences [1-3]. Therefore, the efficiency of flashflood management strategies are dominated to large extents by the quality of available data, field measurements and verifications [4]. Traditionally, topographic maps have been used for decades as the primary source to derive hydrographic and hydrologic elements. Issues related to availability, scale and data consistency are among the main problems that delimit the capabilities of traditional topographic maps in the hydrological modelling $[5,6]$. 
Recently, the digital elevation models (DEMs) are increasingly used in hydrological modeling and in water resources management studies [7-9]. Various sets of quantitative and spatially-distributed parameters can be automatically derived with high accuracy using different software and algorithms [4,10-15]. DEMs can be generated from different sources, including conventional ground survey, topographic maps, stereo-photos or satellite images, radar interferometry, and laser scanning [16-19].

The recent developments in remote sensing and Geographic information system (GIS) have positively reflected on the availability and resolution of DEMs. The Shuttle Radar Topography Mission (SRTM), and the Advanced Spaceborne Thermal Emission and Reflection Radiometer Global Digital Elevation Model (ASTER GDEM), Advanced Land Observing Satellite-1 (ALOS) Phased Array type L-band Synthetic Aperture Radar (PALSAR) and ALOS World 3D-30 m (AW3D30) are examples of the near-global coverage of DEMs that are widely being used in hydrological modelling studies. The consistency of data acquisition and the free access of remote sensing-DEMs are among the key advantages that promoted their widespread use in the hydrological and geomorphological modelling [20,21]. However, these remote sensing-DEMs may encompass numerous artefacts that can limit their proper implementation. For example, SRTM data may contain numerous voids (regions with no data) and other spurious cells (spikes or sinks), therefore editing is required before using them. Moreover, coastlines and sandy plains are typically not well detected in the SRTM, due to its low dielectric constant, surface roughness and consequently the low radar backscattering [22].

Basically, the estimated flow parameters are crucial for flash-flood analyses and the mitigation measures depend mainly on these calculations. Absence or limited availability of in situ measurements and observations remain the key challenge for hydrological modelling in hyper-arid environments. Therefore, the plethora of used models and results obtained in most of the hyper-arid catchments are typically associated with great deal of uncertainty [4]. However, remote sensing data can be used to provide essential data for flash-flood modelling including the active channel pathways, extent, width, recurrence and mapping of induced changes. Combining field surveys with the estimated parameters of the active channels can be used to calculate the peak discharge rates at given cross-sectional areas. Indeed, the peak discharge rates are among the most significant parameters in flashflood analyses. It is important to ensure the capacity of conveying channels, culverts and bridges to contain these peak flow rates, thus the inhabited areas, networks and structures remain safe $[23,24]$.

The variations in the acquisition time of satellite data that are typically utilized to generate the DEMs can be problematic in hydrological and topographic analyses [25]. The land use and land cover changes over time can significantly modulate the landscape and therefore change the ground elevation in certain areas and thus affect the flow directions and inundation areas $[4,26,27]$. Examples of these changes include; the construction of asphalt roads, urban sprawls over agricultural and rural land, the removal of forest lands and mining and industrial activities. Moreover, the different spatial resolution of the generated DEMs from different sources (e.g., SRTM: pixel size of 30 and 90 m; ASTER DEM: pixel size of $30 \mathrm{~m}$; ALOS PALSAR DEM: pixel size of $12.5 \mathrm{~m}$ ) and the fact that DEM pixel averages the ground elevations within the pixel [28] necessitate the examination of the sensitivity of the quantitative estimates of hydrological and flash floods parameters from different DEMs as well as assessing the impact of land use/land cover changes on these parameters [26,29-33]. 
The Nile Valley in Egypt is among the heavily populated and occupied areas in the dryland regimes, it occasionally receives severe flash floods from the tributary wadis, which drain the fringing plateaus in the Eastern and Western Deserts [4,27]. Therefore, the integrated management strategies for flash floods are of societal and environmental importance, as the discharge of flash floods and associated sediment load (i.e., turbidity) into the Nile River could usually disrupt potable water supplies for short periods. Thus, the critical storage of flash floods into the alluvial channels will not only reduce sediment load into the Nile course, but also will enhance the recharge of the fragile groundwater aquifer of these wadis.

This paper aims to examine the hydrological and environmental aspects of flash floods delivered to the northern sector of the Nile Valley in Egypt from two main watersheds, namely Al Rishrash and Atfeh catchments under conditions of hyper-aridity and scarce in situ data. To achieve this objective, the study will: (1) analyze the land use in the context of the geomorphological and geological settings using satellite observations (i.e., Landsat images), thus the vulnerability to flash flooding can be determined, (2) investigate the morphometry of drainage basins and identify the existing flash-flood measures, (3) estimate the flash-flood parameters using spatially distributed unit hydrographs given various sets of available DEM sources, thus the sensitivity of quantitative analyses to these different data sources can be examined, and (4) propose recommendations for an optimum strategy for flash-flood mitigation measures based on the contemporary setting of anthropogenic activities, in order to minimize the negative impacts and to increase benefits from these occasional hydrological resources.

\section{Study Area}

The development of the Nile River in Egypt has been controlled by the Red Sea rifting during the Oligo-Miocene, where the initiated rift-related graben between the Eastern and the Western Deserts accommodated the Nile floodplain [9,34-36]. Consequently, the elevated Eocene limestone plateau in the north Eastern Desert of Egypt has been incised by numerous wadis that drain this plateau into the Nile River [8]. The Nile Valley between the Beni Suef Governorate and the Greater Cairo (i.e., the study area; Figure 1) is one of the key heavily populated areas in Egypt. The availability of land parcels suitable for urban growth has become very limited. As a result, the alluvial plains and nearby foot slopes of the eastern limestone plateau has been targeted for different anthropogenic activities. The development of the Nile River through sets of distinctive phases of evolution (i.e., the Paleonile, the Protonile, and the Prenile) as well as the water discharge from catchments draining the surrounding plateau has contributed to the accumulation of groundwater, fertile soil and building raw materials. The catchments of Wadi Al Rishrash and Atfeh drain approximately $618 \mathrm{~km}^{2}$ and $428 \mathrm{~km}^{2}$ of the plateau and ends into the Nile River at cities of El Wadiy and Atfeh respectively (Figure 1). New agricultural areas have been reclaimed on the expense of the fertile soil of the Prenile and the Paleonile. Most of the new cultivations are being irrigated from the Nile via sets of pumping stations and networks of pipes and canals. Due to the proximity of the study area to Greater Cairo and its nearby new urban communities, the quarrying of raw materials (i.e., sand, aggregates, and clays) has become one of the main activities. The extraction of these raw materials has created significant changes in the landscape, where large man-made depressions and dump sites are now dotting the area [4]. Most of these depressions are filled with waste water that could negatively affect the surrounding anthropogenic activities as well as the environment. 


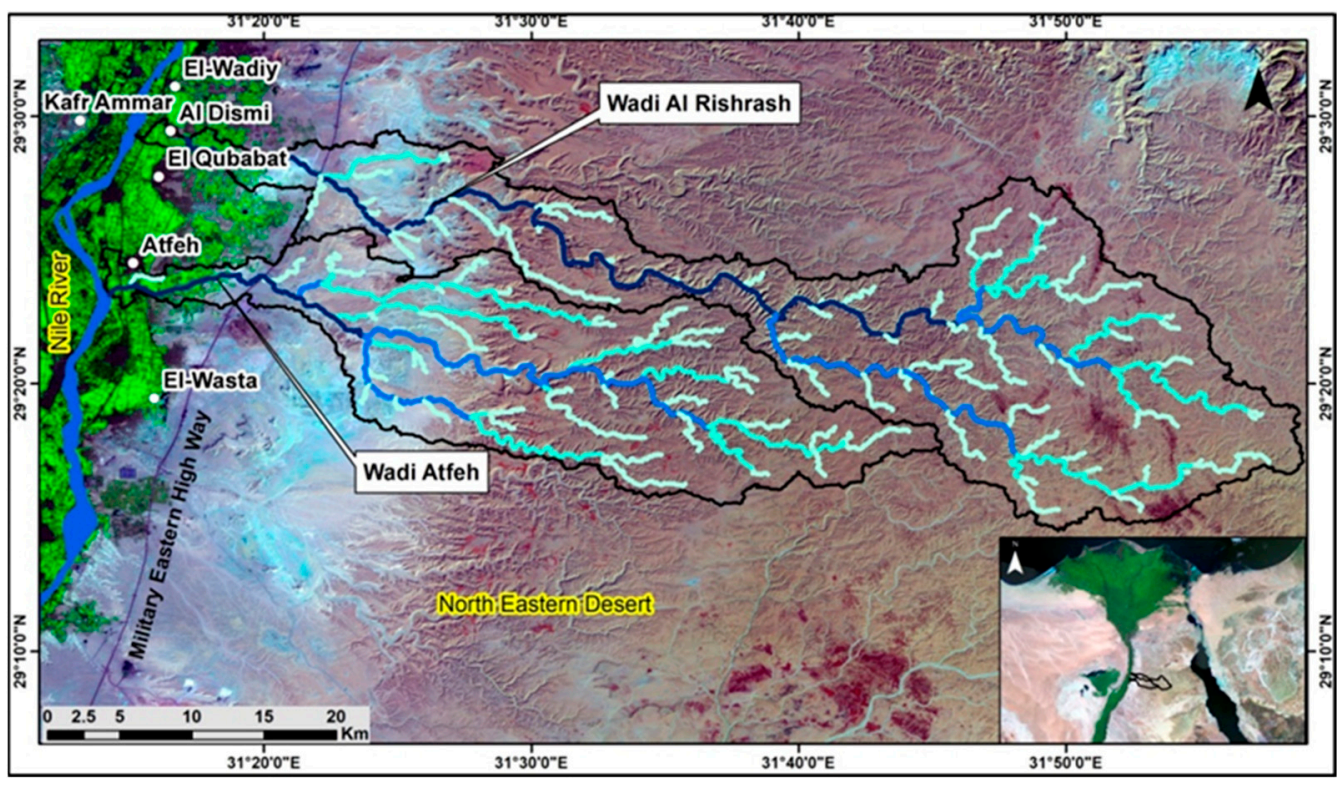

Figure 1. Location map of the study area, showing the location of the Wadi Al Rishrash and Wadi Atfeh catchments and their major stream networks superimposed on a Landsat 8 false color composite image.

Geologically, the study area is a part of the Maaza carbonate plateau and is underlain by sedimentary rock units that range from the Eocene to the Holocene (Figure 2). Successions of carbonate and argillaceous rock units (i.e., Kom El Shelol and Rayan Formations) constitute the oldest rock units exposed in the plateau area [37]. Incursion of the Tethys into the Nile graben during the marine transgression of the Pliocene has deposited the clays of Kom El Shelol as well as other undifferentiated clay and sand deposits. The Nile has developed sets of distinctive units of alluvium during its Quaternary evolution (i.e., Nile silt and wadi deposit), depending on the source areas for weathering in the Nile catchments. Geomorphologically, the plateau area has been dissected by several wadis that debouch into the Nile River (Figure 3). Some of these wadis are characterized by the development of hanging valleys, kinks and dry waterfalls in their upper reaches. These abrupt changes in gradients indicate the significant impact of base level changes and fluvial incision on the studied catchments. Consequently, the wadi courses in the alluvial plains have well-defined trunks rather than braiding patterns. However, quarrying activities and land reclamation has encroached the alluvial plain, thus the flow directions are no longer contained in well-defined paths. Therefore, the vulnerability for flash flooding in the reclaimed alluvial plains, as well as the Nile flood plain, has to be determined. Quantitative and comparative assessment of the flash-flood parameters are discussed in the following sections. 


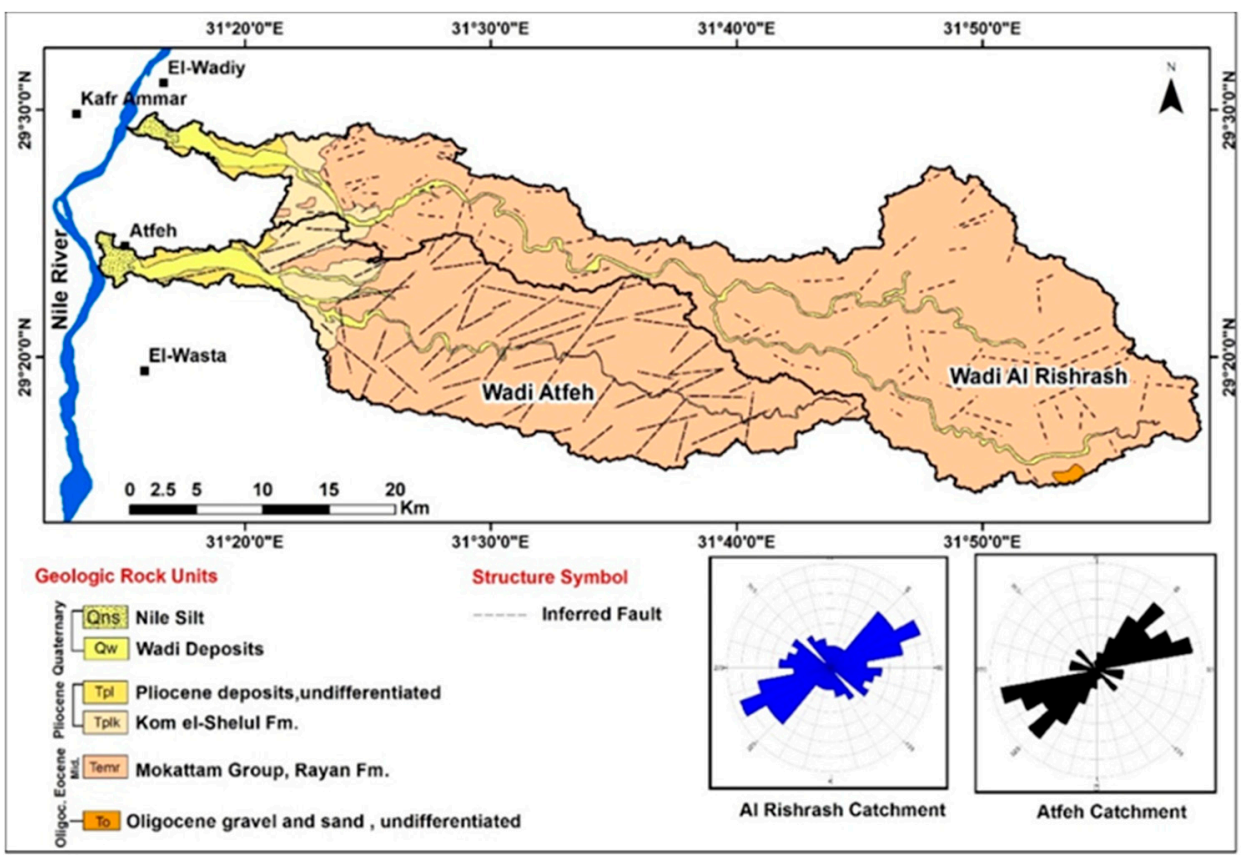

Figure 2. Geological map of the Wadi Al Rishrash and Wadi Atfeh catchments and an inset of the rose diagram showing the dominant structural orientations in the study area, modified after Klitzsch et al. [38].

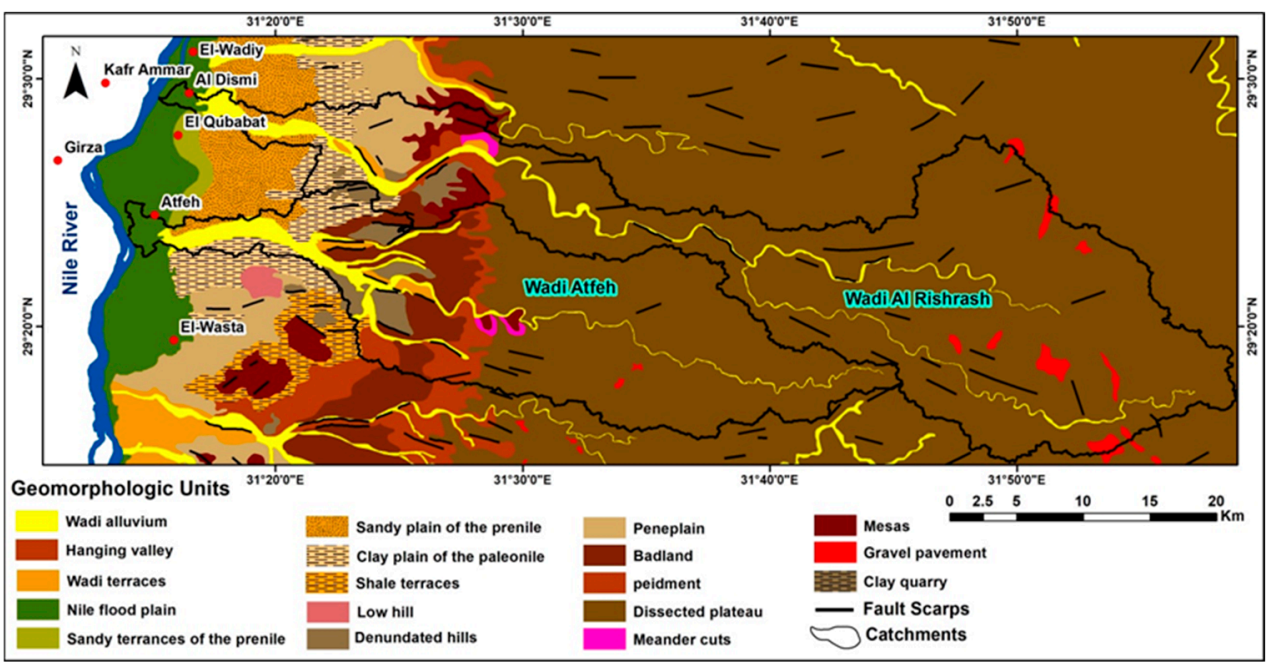

Figure 3. Geomorphological map of the Wadi Al Rishrash and Wadi Atfeh catchments showing the major landforms in the study area.

\section{Materials and Methods}

\subsection{Data Used}

The hydrological analyses of the drainage basins in the study area required the preparation and processing of different sets of DEMs (Figure 4), optical and radar remote sensing data and field observations. The DEM data sets include (1) topographic maps with a scale of 1:50,000 surveyed and mapped in 1988, which have been digitized and processed to produce a DEM with 30 and $90 \mathrm{~m}$ pixel size (i.e., spatial resolution). (2) SRTM DEM (acquired in 2000) with 30 and $90 \mathrm{~m}$ resolution. (3) ASTER DEM (produced) with $30 \mathrm{~m}$ resolution. (4) AlOS PALSAR DEM (produced in 2006) with $12.5 \mathrm{~m}$ resolution. The satellite images include Landsat TM and Landsat 8 OLI (with $30 \mathrm{~m}$ resolution) (path 176; row 40) in order to detect the active channel pathways and imprints of flash floods as well as to map the land use and landcover changes and their relevance for the hydrological 
analyses. The field observations were taken shortly after the flash-flood event of March 2020 in order to verify the hydrological imprints and interpretation from the Landsat 8 acquired on April, 2020.

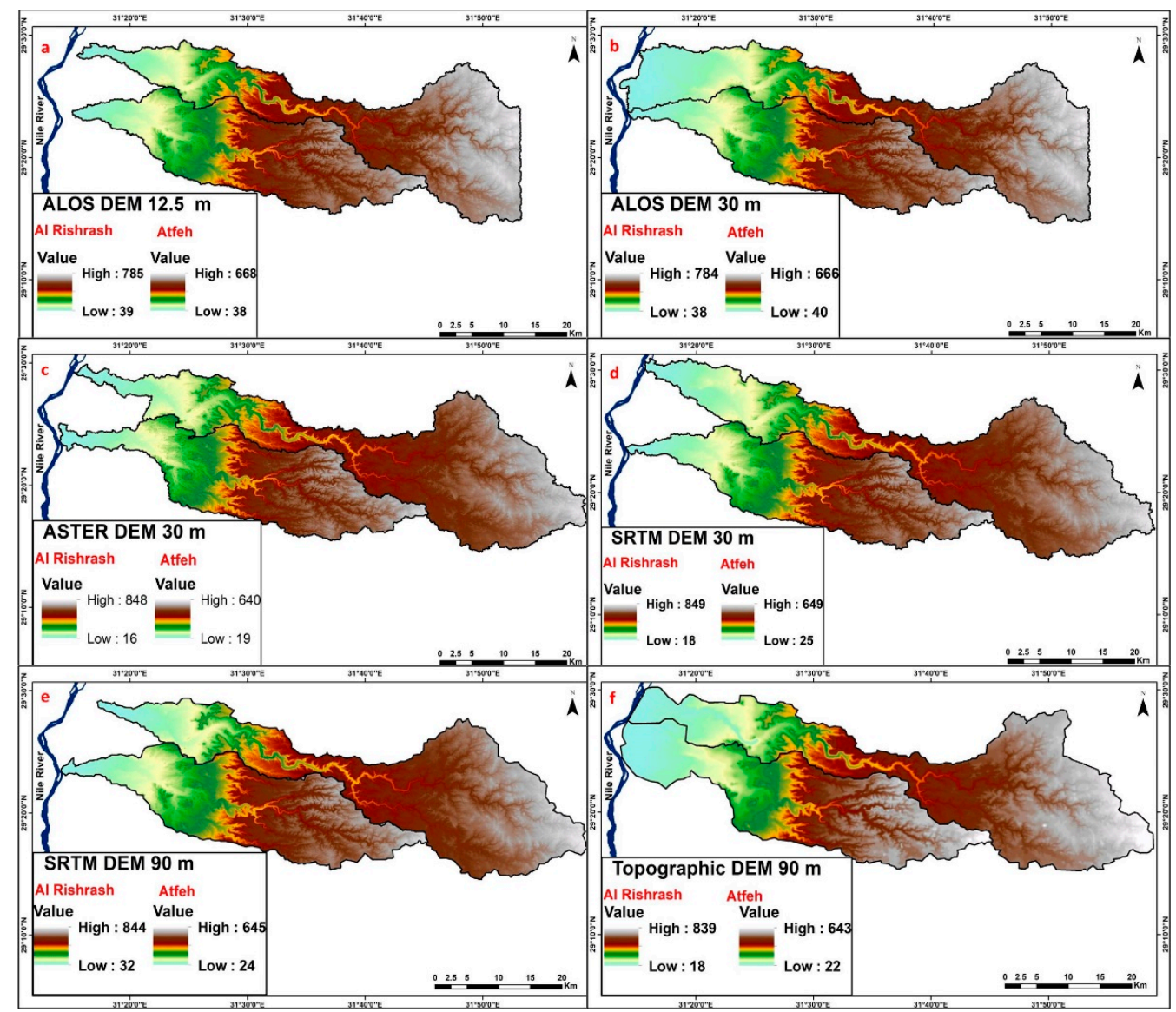

Figure 4. Examples of different DEMs sources used in hydrological analysis of Wadi Al Rishrash and Wadi Atfeh catchments including (a): ALOS DEM (12.5 m resolution), (b): ALOS DEM (30 m resolution), (c): ASTER DEM (30 m resolution), (d): SRTM DEM (30 m resolution), (e): SRTM DEM (90 $\mathrm{m}$ resolution) and (f): topographic map-derived DEM (90 m resolution).

\subsection{Estimation of the Hydrographs}

ArcHydro is a GIS toolbox for hydrographic analysis, which provides the basis for hydrological data modelling [39]. The different datasets and layers have been co-registered and projected into WGS UTM zone 36, datum 1984. Each of these DEMs has been processed following the standard steps in ArcGIS 10.3 software in order to compute the GIS-spatially distributed unit hydrograph for the two catchments from a uniform storm with an effective rainfall depth of $10 \mathrm{~mm}$. This value represents the minimum streamflow initiation threshold in the Sahara as determined from field measurements and was widely used for flash-flood assessment in desert environments [23]. This hypothetical uniform rainstorm event was preferably selected over using historical records of rainfall events in the Eastern desert of Egypt due to the absence of continuous gauges in these desert watersheds and the extreme variability of the rainfall events in time and space [23,40]. In order to compute the hydrographs, several steps are involved in a GIS environment that include the subdivision of catchments into cascading zones and estimation of the effective discharge of each zone on time graphs.

The specific steps are as follow: (1) the DEMs were "filled" to raise the elevation levels of error-sink holes (i.e., depressions) to their neighboring elevations of surrounding pixels to ensure the flow transmission to the catchments outlets [10]. These error- sink 
holes can result from data acquisition and/or processing of the elevation grids, and can be distinguished from existing natural or artificial depressions in the landscape from the landuse/landcover maps and satellite images, (2)the flow direction maps have been computed from the "filled" DEMs in order to derive the direction (i.e., aspect) and gradient of the flow from each cell into its neighboring ones guided by the D-8 algorithm [41], (3) the "flow accumulation" was calculated from the "flow direction", thus the spatially distributed upstream flow contributing areas for both of the catchments and the drainage networks can be given at any cell [42]. A threshold of $1.2 \mathrm{~km}^{2}$ for the flow accumulation was selected to represent the minimum up flow contributing areas to initiate a drainage line. Of course this threshold area will equate different numbers of cells given the resolution of used DEMs, (4) the "flow length" for each catchment was computed using the flow directions and accumulations in order to estimate the total length of overland flow and channel flow from any location (cell) in the catchments to the final outlet, (5) the spatial analyses functionalities were used to compute the "time of flow map" based on the application of open channel flow equations (e.g., the Manning equation), which incorporates the gradient, the roughness as a function of lithology of the hillslopes and the channel fills, and the channel geometry (i.e., cross sectional area). The average channel flow velocity was estimated as $2 \mathrm{~m} / \mathrm{sec}$. This value is consistent with in-situ measurements of recently occurred flash-flood over the Maaza plateau, nearby the study site [4]. Moreover, the uniform lithology of the hillslopes, which is mainly composed of limestones (Figure 2), makes it feasible to apply a constant channel flow velocity for the entire spatially distributed flow lengths, (6) then, the "time-area zones" have been obtained (Figure 5) from the clustering (i.e., reclassification) of the "time of flow map" in order to subdivide the catchments into sets of cascading and consecutive zones (areas in square kilometers), each will deliver the resulting channel flows to the outlet at specific time (in hours), and (7) finally, the hydrographs have been calculated from the time- area zones and the application of a $10 \mathrm{~mm}$ rainfall event over the catchments. The resulting hydrographs are expected to vary according to the temporal and spatial changes in the storm, where the magnitudes and discharges from the different sub-catchment will occur.

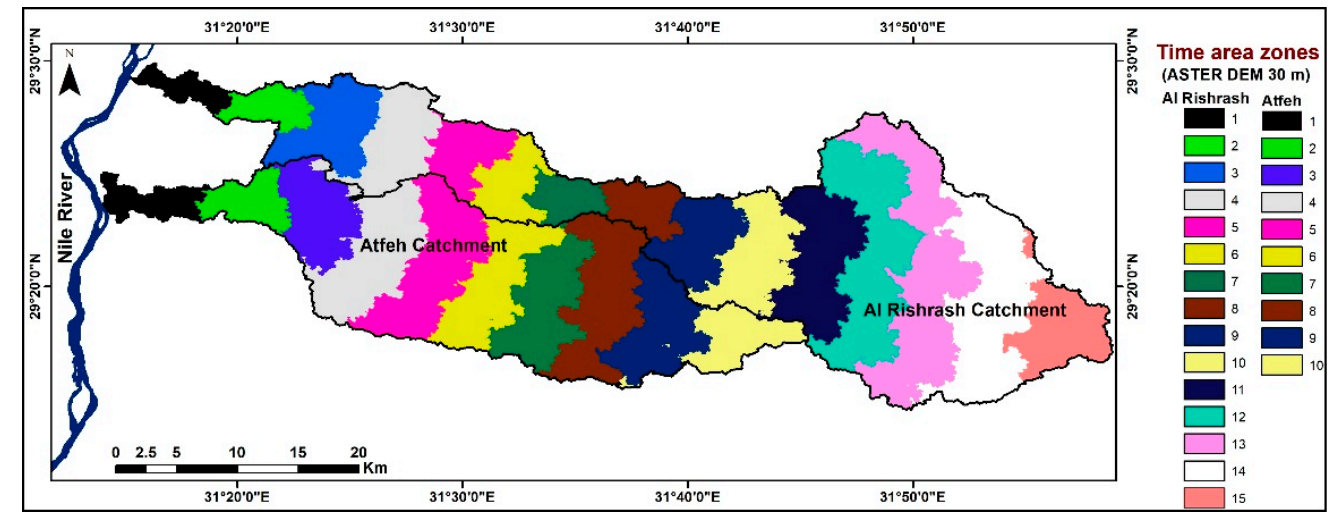

Figure 5. Time-area zones estimated from the derivatives of the ASTER DEM (30 m).

\section{Results}

In this section, the qualitative and quantitative analyses of the topographic, hydrologic parameters from the different sets of DEMs and remote sensing data are given as follows:

\subsection{Topographic Analyses}

Elevation ranges of the study area are approximately similar on the various sets of DEMs, with minor changes in the pattern and extent of the low-laying areas in the outlets of drainage basins, which are occupied by the alluvial and Nile-flood plain. The main advantage of creating a DEM from the topographic maps surveyed several decades ago (i.e., 1988), is the ability to reveal the landform setting in the alluvial plains, which are currently 
reclaimed and encroached as appeared on the recent satellite images. Furthermore, the portrayed relief of wadis downstream and alluvial plains are more informative compared with the other datasets, because the incorporation of the drainage lines in the interpolation processes imposes subtle changes in the selected active channels than surrounding areas. The key advantages of using recently-acquired DEMs from the different remote sensing optical and radar platforms are their capabilities to keep track on the ever-evolving man-made structures such as quarry pits, conveying channels and check dams that can cause accumulation of flash-flood water and alter the flow direction and thus affect the vulnerability of rural and urban areas to flash flooding $[43,44]$. The pathway of flash floods from the Atfeh basin has been controlled by the constructed embankments, which are elevated compared to the surrounding areas. This artificial embankment clearly appear on the satellite images from 1994. The relief signature for this man-made conveying channel has been recognized only on the ASTER DEM of $30 \mathrm{~m}$ resolution (Figure 6). The main advantage of ASTER DEM is the compilation of surface relief from the mosaicking of stereoscopic images, thus any surface details can be included in the resulting DEM.

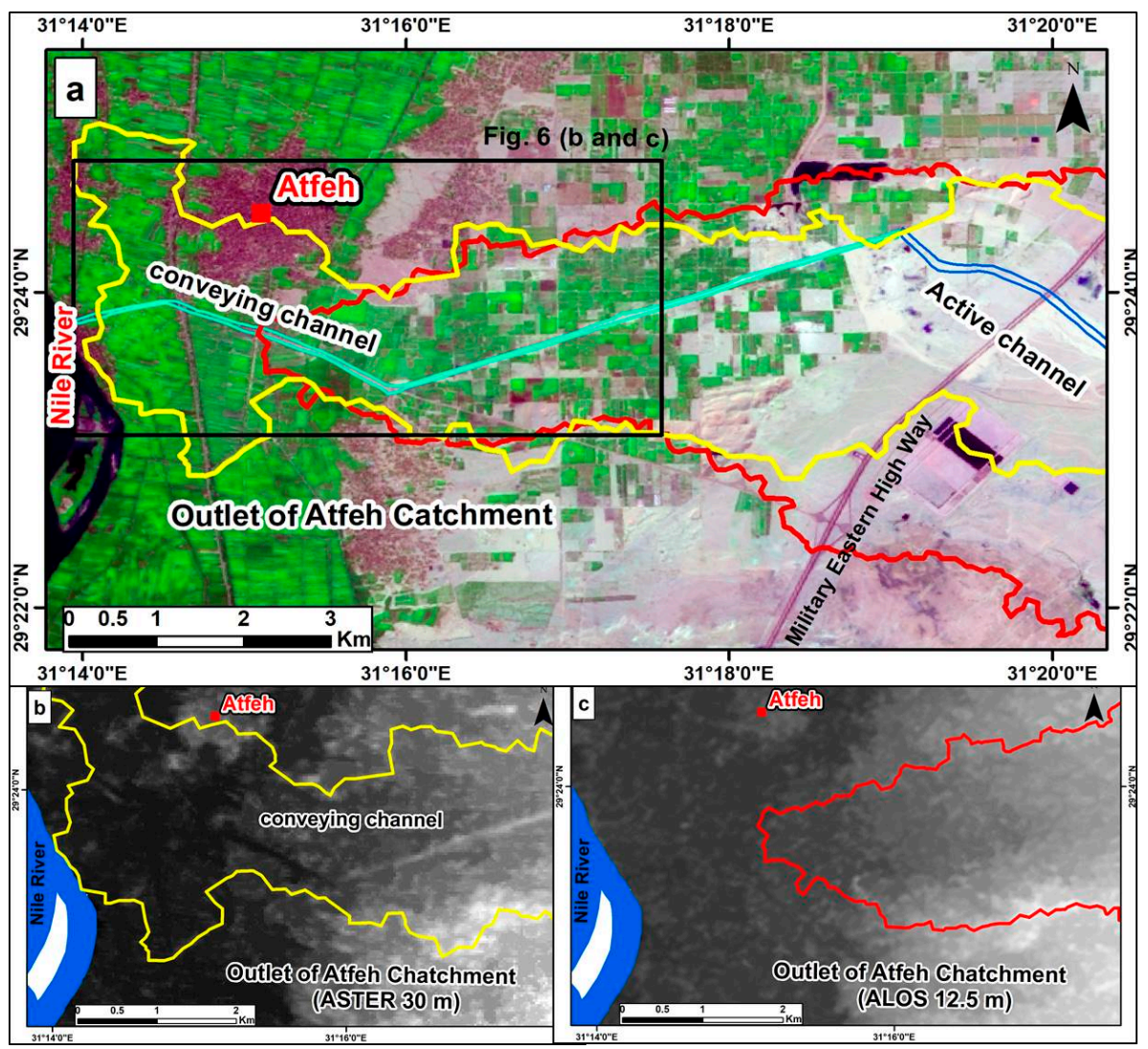

Figure 6. (a) Landsat 8 image of the outlet of Atfeh catchment showing the catchment boundary from different DEM sources (ASTER DEM in yellow and ALOS DEM in red) as well as the conveying channel. The relief signature of the man-made conveying channel can be recognized only on the ASTER DEM of $30 \mathrm{~m}$ resolution (b) but not on the ALOS DEM $12.5 \mathrm{~m}$ resolution (c). Note that the automatic extraction of the catchment boundary using ALOS DEM yielded a smaller catchment compared to the one derived from the ASTER DEM, where the catchment outlet on the former DEM occur at $\sim 1.5 \mathrm{~km}$ away from the Nile River compared to reaching the Nile River on the later (refer to Figure 4 for a regional overview of the two catchments).

However, the ALOS PALSAR DEM is available at a higher horizontal resolution $(12.5 \mathrm{~m})$ than the ASTER DEM, but this specific elevated feature has not been portrayed. Similarly, the SRTM data (both 30 and 90 m DEM) has not showed these elevated embankments. The blurred surface expressions of these elevated linear features could be related to 
the technical characteristics of the SRTM and ALOS PALSAR datasets. These DEMS have been mainly generated from radar images, which are capable of penetrating the shallow alluvial surface layer. On the other hand, this penetration capability notably improves the detection of paleo and buried channels in the dryland areas such as the buried rivers in the Sahara [45].

\subsection{Hydrological Analyses and Resulting Hydrographs}

The quantitative indices of the two drainage catchments have been estimated from the hydrographs (Figure 7) and were summarized in Table 1. For example, the time to peak represents the required time to attain the highest discharge and the total flow duration indicates the entire length of time required to discharge all the flash-flood out of the catchment outlet. Inspection of these parameters indicates a high similarity between the outputs of different DEM sources and are approximately consistent with wadis and alluvium extent on the satellite images. Moreover, the estimated unit hydrographs from a $10 \mathrm{~mm}$ effective rainfall uniformly distributed in one hour over the entire time-area zones are highly correlated (Figure 7). For example, the unit hydrographs for the Atfeh catchment ranges in total flow duration from 10 to $12 \mathrm{~h}$ and the peak discharge rate vary from $89 \mathrm{~m}^{3} / \mathrm{s}$ (SRTM $30 \mathrm{~m}$ ) to $102 \mathrm{~m}^{3} / \mathrm{s}$ for the ALOS DEM. The time-to-peak occurs in the fourth hour in all data sets except in the ASTER $30 \mathrm{~m}$ DEM, which produced a peak discharge in the third hour. The SRTM DEMs appears to produce the modest slope and gradient as the catchment has been subdivided into large numbers of cascading time-zones.

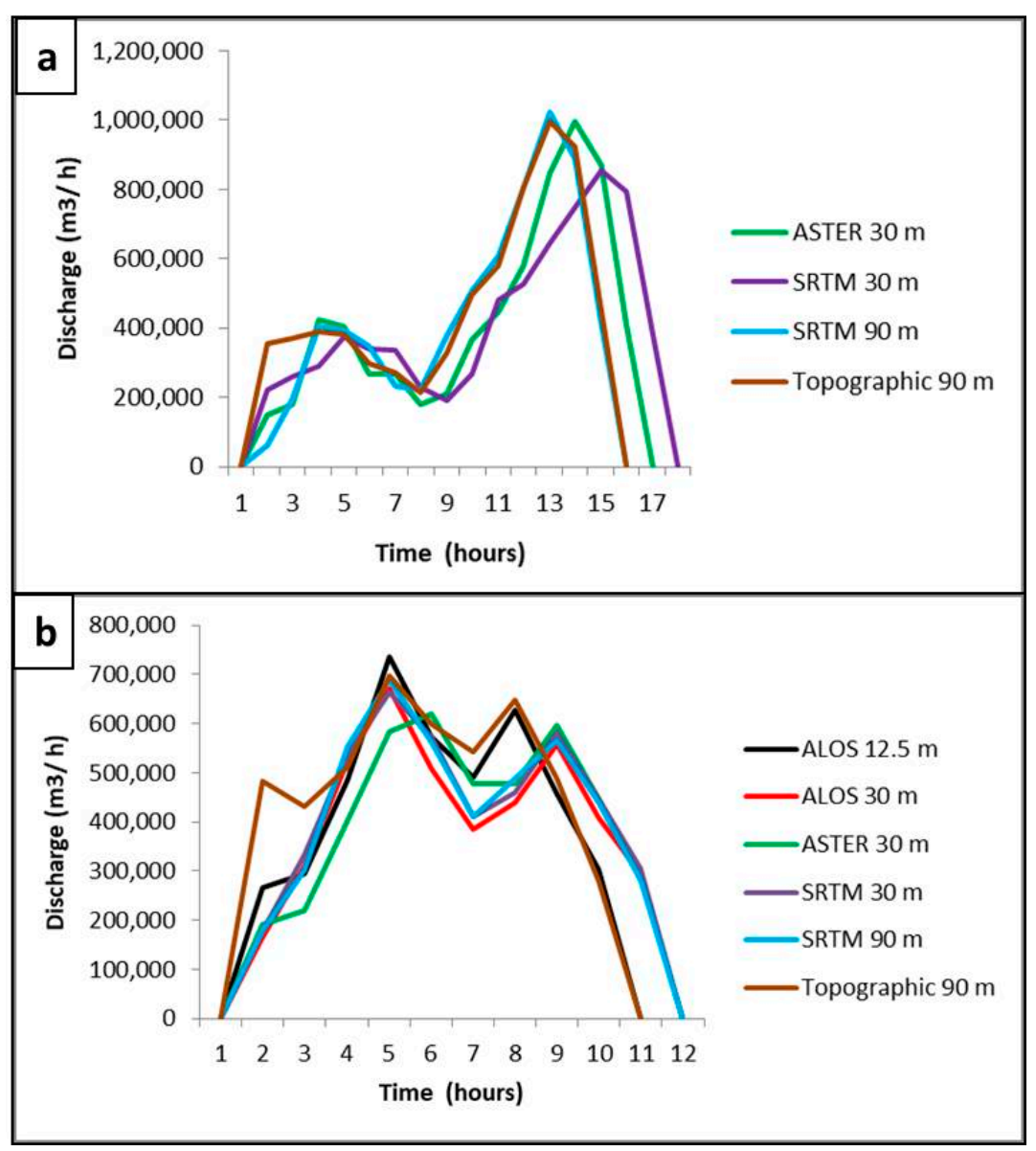

Figure 7. Simulated unit hydrographs for the Wadi Atfeh (a) and Wadi Al Rishrash (b) catchments using the estimated runoff coefficient from different DEMs. 
Overall, using constant inputs of effective rainfall and fixed routing and losses of the overland and channel flows, the resulting quantitative changes in flow parameters from the different sets of DEMs are small and of subtle significance on the magnitudes of hydrographs. Indeed, changes of the contributing physical parameters of rainfall/runoff distribution, extent and magnitudes over the catchments are responsible for the huge changes that characterize the flash-flood flows from one event to another and among the different catchments.

Table 1. Morphometric parameters of the different drainage catchment.

\begin{tabular}{|c|c|c|c|c|c|c|c|c|}
\hline Location & DEM Source & $\begin{array}{c}\text { Area } \\
\left(\mathbf{k m}^{2}\right)\end{array}$ & $\begin{array}{c}\text { Total Flow } \\
\text { Discharge } \\
\left(\mathrm{m}^{3}\right)\end{array}$ & $\begin{array}{c}\text { Peak of Flow } \\
\text { Discharge } \\
\left(\mathrm{m}^{3} / \mathrm{s}\right)\end{array}$ & $\begin{array}{l}\text { Total Flow } \\
\text { Duration } \\
\text { (h) }\end{array}$ & $\begin{array}{l}\text { Time to } \\
\text { Peak (h) }\end{array}$ & $\begin{array}{c}\text { Maximum } \\
\text { Flow Lengths } \\
(\mathrm{km})\end{array}$ & $\begin{array}{l}\text { Total Stream } \\
\text { Lengths } \\
\text { (km) }\end{array}$ \\
\hline \multirow{5}{*}{$\begin{array}{l}\text { Al Rishrash } \\
\text { Catchment }\end{array}$} & SRTM $90 \mathrm{~m}$ & 617.8 & $6,472,872$ & 141.9 & 14 & 13 & 101.5 & 332 \\
\hline & SRTM $30 \mathrm{~m}$ & 658.2 & $6,935,814$ & 118.7 & 16 & 14 & 109.3 & 372 \\
\hline & ASTER $30 \mathrm{~m}$ & 624.9 & $6,585,291$ & 138.1 & 15 & 13 & 103.9 & 333 \\
\hline & $\begin{array}{c}\text { ALOS PRISM } 30 \mathrm{~m} \\
\text { ALOS } 12.5 \mathrm{~m}\end{array}$ & & & & & & & \\
\hline & Topographic $90 \mathrm{~m}$ & 685.0 & $6,847,740$ & 138.4 & 14 & 13 & 99.6 & 321 \\
\hline \multirow{6}{*}{$\begin{array}{c}\text { Atfeh } \\
\text { Catchment }\end{array}$} & SRTM $90 \mathrm{~m}$ & 428.2 & $4,471,281$ & 95.9 & 10 & 4 & 69.4 & 263 \\
\hline & SRTM $30 \mathrm{~m}$ & 426.3 & $4,492,359$ & 92.3 & 10 & 4 & 70.8 & 291 \\
\hline & ASTER 30 m & 409.0 & $4,309,605$ & 86.1 & 10 & 6 & 70.5 & 257 \\
\hline & ALOS PRISM $30 \mathrm{~m}$ & 426.2 & $4,262,616$ & 93.2 & 10 & 5 & 70.4 & 279 \\
\hline & ALOS $12.5 \mathrm{~m}$ & 423.6 & $4,236,148$ & 102.2 & 9 & 5 & 70.9 & 276 \\
\hline & Topographic $90 \mathrm{~m}$ & 467.9 & $4,678,884$ & 96.9 & 9 & 5 & 65.5 & 249 \\
\hline
\end{tabular}

\subsection{The Environmental Impacts of the March 2020 Flash Flood Event}

The extent and magnitudes of the flash-flood event of 13 March 2020 were highly variable among the different drainage basins. This variability sheds light on the importance of understanding the controlling physical processes and anthropogenic activities on flash floods, which are needed to alleviate their adverse environmental and societal impacts. Inspection of multi-temporal Landsat 8 images before and after the March 2020 flash-flood event in the two catchments (Figures 8 and 9) together with filed observations indicates that: (1) the alluvial plains, which are liable to occasional flash flooding, have been reclaimed for agricultural activities, encroached by rural and urban areas, and locally exploited for quarrying for raw and building materials. (2) The culverts underneath the Eastern Military Road are of insufficient capacity to discharge the peak flows. Thus, the road at its intersections with the main wadi is vulnerable to accumulation of runoff and flooding. The destruction of the road section in Wadi Al Rishrash during the 13th of March event drifted several vehicles with serious causalities and life losses (Figure 10). (3) The conveying channels west of the Military road have been breached by overflows during the last flash floods, thus the agricultural fields has been flooded, and the near-by open pit quarries have also received considerable amount from the flash flooding (Figures 8 and 9), and (4) the villages in the Nile Valley have been affected by the flash floods, and Al Dismi has been severely affected by the flash-flood from Wadi Al Rishrash, where buildings in the wadi floor were flooded and several houses on the wadi banks collapsed due to erosion of the bank sediments underneath (Figure 10). 


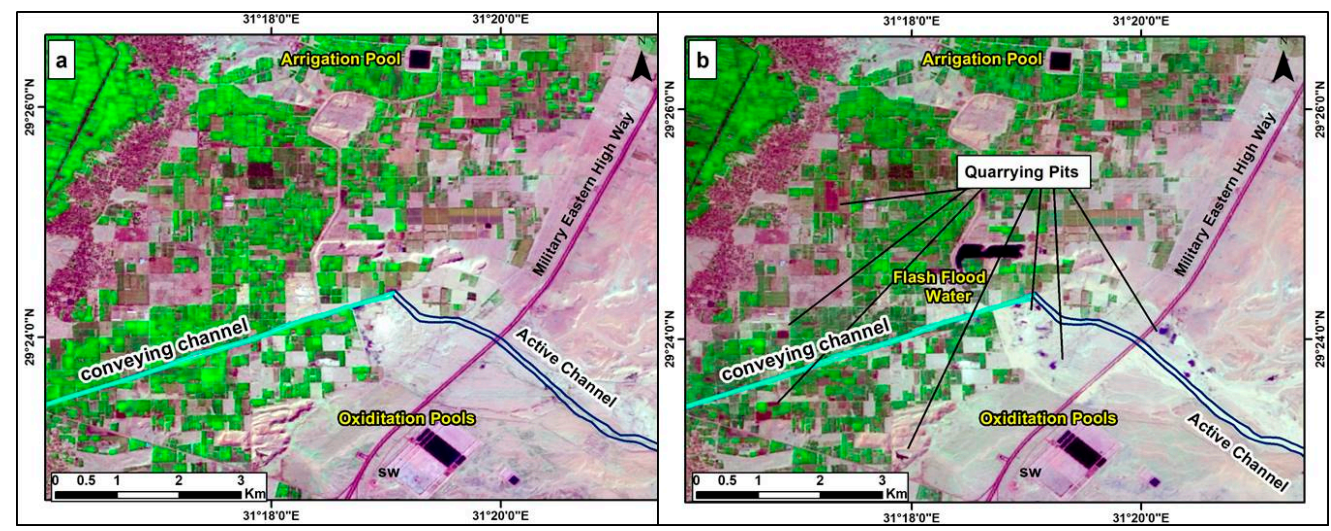

Figure 8. Multi-temporal Landsat 8 image close-up on the outlet of Wadi Atfeh catchment before (a) and after (b) the flash-flood event of 13 March 2020 showing the water accumulation in quarrying pits.

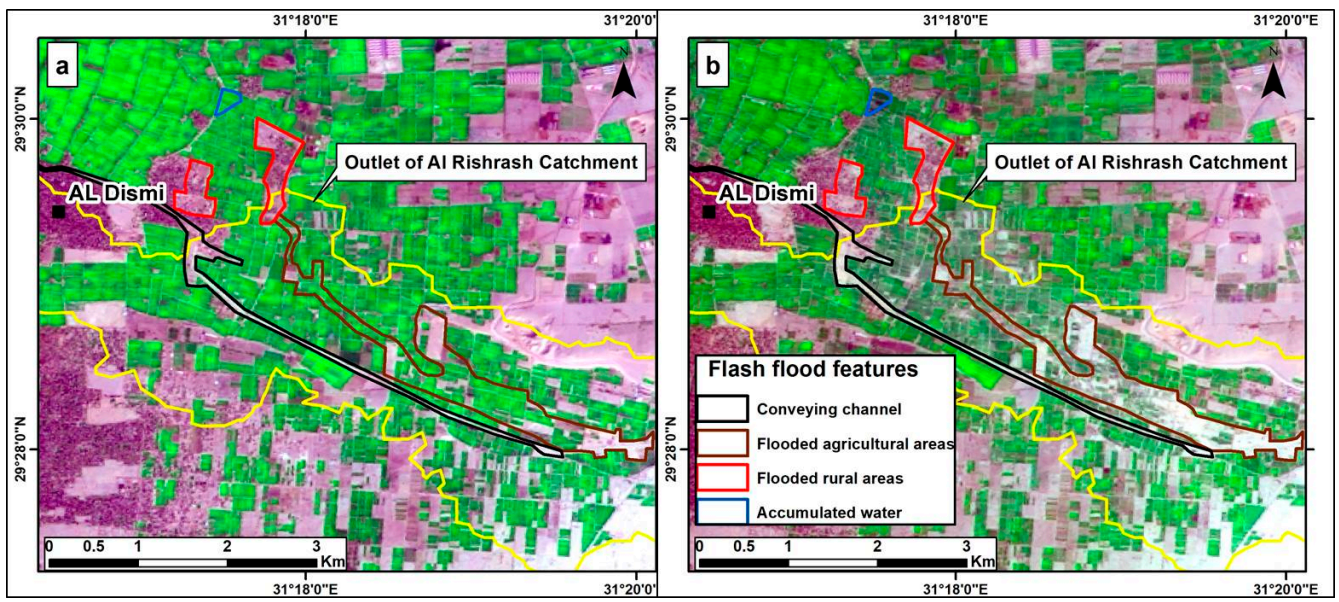

Figure 9. Multi-temporal Landsat 8 image close-up on the outlet of Wadi Al Rishrash catchment before (a) and after (b) the flash-flood event of 13 March 2020 showing the overflooding of the conveying channel, drowning of the agricultural lands, flooding of villages and urban areas and accumulation of water ponds.

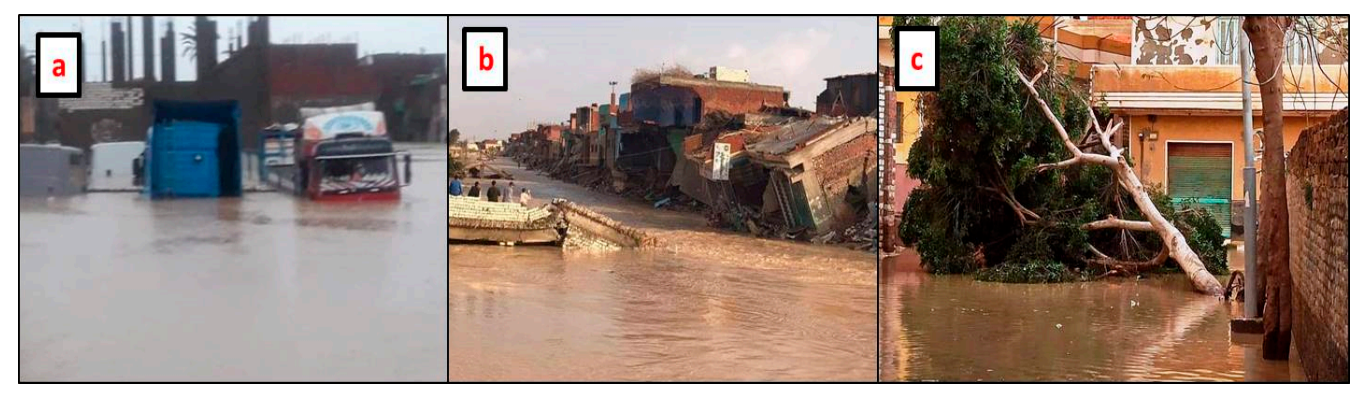

Figure 10. Field photographs showing the destructive impacts along the intersection of the outlet of the Wadi Al Rishrash catchment at the Al Dismi village after the flood event of 13 March 2020, including damage of vehicles (a) drowning of urban centres (b), and damage of trees (c). The location of the Al Dismi village is highlighted in Figure 1.

\section{Discussion}

Under the current hyper-arid conditions, the investigated catchments remain dry for several years and could be liable to flash flooding only during short events of rainy storms that could generate runoff. Inspection of the multi-temporal Landsat-8 (Figures 8 and 9) shows that wadi floors along the outlet of the investigated catchments have attracted 
people to establish urban and agricultural activities regardless of the high vulnerability to flash floods. This is mainly related to the lack of social awareness and scientific attention to better understand the flash-flood hazards and potential risks. The recurrence of severe storms/flash floods over these catchments during the last decade has revealed the need to better understand the flash-flood processes and their interaction with the anthropogenic activities. The insufficiency of adopted mitigation measures to control the hazards of flash floods have also revealed the drawbacks of estimating the hydrological parameters using uncalibrated and non-validated hydrological models that fit with the dryland environments. The previously-employed models in these ungauged catchments $[4,23,24]$ followed the rational approach in which the catchment parameters are lumped. Therefore, the estimated hydrographs for different catchments are more or less of same configuration with changes occur in magnitudes and total time of flows. Again, these models were never tested due to the absence of gauging measurements and field observations.

The findings from the analysis of different DEMs and Landsat images indicate that the use of remote sensing and DEMs to model the flash floods are convenient tools to derive quantitative estimates, which are very difficult or impossible to obtain as the catchments are ungauged by rainfall and runoff measuring stations. Moreover, the DEMs of different sources are of comparable quality and results and thus it is not probably a necessary task to analyze different DEMs to obtain more accurate estimations of the flash-flood parameters under such conditions of hyper-aridity and scarce rainfall and stream flow data. Instead, a great deal of attention should be paid to understand the morphological and geological setting of the different basins to better manage the flash floods. This assumption is evidenced by the significant changes in the shape of the hydrographs and the different flash-flood parameters between the two adjacent catchments (e.g., time-to-peak is $14 \mathrm{~h}$ in the Al Rishrash catchment compared to $4 \mathrm{~h}$ in Atfeh catchment using the same SRTM of $30 \mathrm{~m}$ resolution). The different basin area (Table 1 ) and probably the different structurally controlled-slope gradients are the main reason for the significant differences between the two catchments, however they are covered by the same lithological units.

Regarding the slight differences in extracted flash-flood parameters from different DEMs, our results are consistent with previous studies carried out in catchments in different areas, where the impact of characteristics of different DEM sources on hydrological modelling has been widely investigated [46-48]. Variations in the derived surface drainage networks from different DEMs are mainly related to the quality, source and resolution of the DEM and to the processing techniques and algorithms employed [49]. There is a general tendency that the catchments of low-resolution DEM generate higher flow volumes and peaks when compared with a high resolution DEM for the same catchment [50]. Our results are also in good consistence with this general tendency however, the quantitative estimates are very similar regardless of the source and resolution of the used DEMs. The controlling parameters responsible for changes in the hydrographs magnitudes and configuration can be attributed to the physical changes in the storm pattern, intensity and distribution as well as the geologic and geomorphologic setting of the catchments themselves. That is why the flash floods, even developed in same wadis, are different from one event to another. The discrepancies in hydrographs of Al Rishrash and Atfeh catchments demonstrate the control of drainage basin morphometry on the magnitudes and time to peak. The two catchments are of pear-like shape in their upper parts, but Wadi Al Rishrash is more elongated in the middle and lower parts than Wadi Atfeh. Therefore, time-to-peak occurs in the middle of flash floods hydrograph in the former, while it occurs in the beginning of the later (Figure 7). Indeed, the timing factor is very crucial in the management and response to the peak discharges affecting the rural and urban areas.

Finally, the abundance availability of remote sensing and DEMs can be used to estimate the flash-flood quantitative parameters, which otherwise are simply not available. The recent flash floods that hit some of the Eastern Desert catchments clearly indicate the necessity for better quantitative estimates of the flow parameters to propose scenarios for mitigation strategies. The issues of safe conveyance of flash floods into the Nile River 
and the storage of flash-flood water into artificial reservoirs in the catchments needs further investigations. In order to avoid the adverse impacts of the flash floods and the associated sediment load into the Nile that can induce turbidity that disrupts the potable water supplies for several days (Figures 8 and 9), it is necessary to select geologicallysuitable sites for dam constructions. These sites should be performed in guidance by investigations of the subsurface setting using appropriate tools such as the geo-electric methods to ensure the creation of flash-floods reservoirs in areas that can promote the recharge of alluvial aquifer. The geo-electric investigations in the study area showed that extent of the impermeable Pliocene clays in the subsurface are of high variability [4]. The hydrogeological development of the Nile ancestors during its complex history of evolution in the Tertiary and Quaternary, and the incisions and down cutting of impermeable layers occurred by the tributary wadi systems during the low-stands of the Mediterranean could be the main factors responsible for the variations and extent of the alluvial/Nile aquifer in the area [4]. It can be concluded that the management of flash floods needs not only understanding and modelling of the torrential flows and its interaction with the land use, but also the implementation of geological and hydrological development of the local as well as the regional settings.

\section{Conclusions}

The wadis of Al Rishrash and Atfeh draining northern part the Eastern Desert of Egypt into the Nile River have been affected by sever flash floods. The event of March 2020 showed negative consequences on the rural and agricultural areas, as well as developing fatalities due to the destruction of roads intersections with main active wadis. The quantitative estimates of flash-flood parameters were carried out using different sets of available DEMs, satellite images and field observations. The hydrographs were estimated using the spatially-distributed unit hydrograph approach assuming constant $10 \mathrm{~mm}$ effective rainfall distribution and induced channel runoff due to the absence of in situ data and measurements. It was found that technical aspects related to sources and resolutions of the datasets impose insignificant control on the quantitative analyses, where flow durations, time to peak and peak discharge rates are almost similar when computed from the different DEM sources. On the contrary, the variations in the geological and geomorphological settings of the catchments are of more significant control on the hydrograph magnitudes and flash-flood analyses. Understanding of geologic and hydrologic evolution of the drainage basins is necessary to propose integrated management strategies for the flash floods/groundwater recharge to advert the negative socio-economic impact and benefit from these occasional flows.

Author Contributions: Conceptualization, Mohammed El Bastawesy, Omnia El Saadawy, Abotalib Z. Abotalib and Ahmed Gaber; methodology, Omnia El Saadawy; software, Mohammed El Bastawesy, Omnia El Saadawy and Abotalib Z. Abotalib; validation, Mohammed El Bastawesy, Omnia El Saadawy, Abotalib Z. Abotalib and Abdullah Othman; formal analysis, Omnia El Saadawy, Abotalib Z. Abotalib and Maysa Taha; investigation, Mohammed El Bastawesy, Omnia El Saadawy and Abotalib Z. Abotalib; resources, Mohammed El Bastawesy, Abotalib Z. Abotalib and Abdullah Othman; data curation, Mohammed El Bastawesy, Omnia El Saadawy and Abotalib Z. Abotalib; writing-original draft preparation, Mohammed El Bastawesy, Omnia El Saadawy and Abotalib Z. Abotalib; writingreview and editing, Mohammed El Bastawesy, Abotalib Z. Abotalib and Ahmed Gaber; visualization, Mohammed El Bastawesy, Omnia El Saadawy and Abotalib Z. Abotalib; supervision, Mohammed El Bastawesy, Abotalib Z. Abotalib and Ahmed Gaber; project administration, Mohammed El Bastawesy and Abotalib Z. Abotalib; funding acquisition, Mohammed El Bastawesy, Abotalib Z. Abotalib and Abdullah Othman. All authors have read and agreed to the published version of the manuscript.

Funding: This research received no external funding.

Institutional Review Board Statement: Not applicable.

Informed Consent Statement: Not applicable.

Data Availability Statement: The data is available on request from the corresponding author. 
Acknowledgments: The authors are grateful to Paolo Paron, the academic editor, and four anonymous reviewers for their constructive and helpful suggestions that significantly improved the overall quality of the manuscript.

Conflicts of Interest: The authors declare no conflict of interest.

\section{References}

1. López-Vicente, M.; Álvarez, S. Influence of DEM Resolution on Modelling Hydrological Connectivity in a Complex Agricultural Catchment with Woody Crops. Earth Surf. Process. Landf. 2018, 43, 1403-1415. [CrossRef]

2. Mouratidis, A.; Sarti, F. Flash-Flood Monitoring and Damage Assessment with SAR Data: Issues and Future Challenges for Earth Observation from Space Sustained by Case Studies from the Balkans and Eastern Europe. In Earth Observation of Global Changes (EOGC); Krisp, J., Meng, L., Pail, R., Stilla, U., Eds.; Lecture Notes in Geoinformation and Cartography; Springer: Berlin/Heidelberg, Germany, 2013.

3. Abbas, M.; Carling, P.; Jansen, J.; Al-Saqara, B. Flash-flood hydrology and aquifer-recharge in Wadi Umm Sidr, Eastern Desert, Egypt. J. Arid Environ. 2020, 178, 104170. [CrossRef]

4. El-Saadawy, O.; Gaber, A.; Othman, A.; Abotalib, A.Z.; El Bastawesy, M.; Attwa, M. Modeling Flash Floods and Induced Recharge into Alluvial Aquifers using Multi-Temporal Remote Sensing and Electrical Resistivity Imaging. Sustainability 2020, $12,10204$. [CrossRef]

5. Nikolakopoulos, K.G.; Geniataki, S.; Gianou, S. Suitability of DSM derived from remote sensing data for automatic drainage extraction. In Remote Sensing for Agriculture, Ecosystems, and Hydrology XVI; International Society for Optics and Photonics: Bellingham, DC, USA, 2014; Volume 9239, p. 92390I.

6. Czubski, K.; Kozak, J.; Kolecka, N. Accuracy of SRTM-X and ASTER Elevation Data and its Influence on Topographical and Hydrological Modeling: Case Study of the Pieniny Mts. in Poland. Intern. J. Geoinf. 2013, 1, 9.

7. De Carvalho, O.A.; Guimarães, R.F.; Montgomery, D.R.; Gillespie, A.R.; Trancoso Gomes, R.A.; de Souza Martins, É.; Silva, N.C. Karst depression detection using ASTER, ALOS/PRISM and SRTM-derived digital elevation models in the Bambuí Group, Brazil. Remote Sens. 2014, 6, 330-351. [CrossRef]

8. Khalil, M.M.; Tokunaga, T.; Heggy, E.; Abotalib, A.Z. Groundwater Mixing in Shallow Aquifers Stressed by Land Cover/Land use Changes Under Hyper-Arid Conditions. J. Hydrol. 2021, 598, 126245. [CrossRef]

9. Yousif, M.; Hussien, H.M.; Abotalib, A.Z. The Respective Roles of Modern and Paleo Recharge to Alluvium Aquifers in Continental Rift Basins: A Case Study from El Qaa Plain, Sinai, Egypt. Sci. Total Environ. 2020, 739, 139927. [CrossRef]

10. Doctor, D.H.; Young, J.A. An Evaluation of Automated GIS Tools for Delineating Karst Sinkholes and Closed Depressions from 1-Meter Lidar-Derived Digital Elevation Data; 13th Sinkhole Conference, NCKRI Symposium 2. pp. 449-458. Available online: https://www.researchgate.net/publication/250998030_An_Evaluation_of_Automated_GIS_Tools_for_Delineating_ Karst_Sinkholes_and_Closed_Depressions_from_1-Meter_LiDAR-Derived_Digital_Elevation_Data (accessed on 23 June 2021).

11. Psomiadis, E.; Tomanis, L.; Kavvadias, A.; Soulis, K.X.; Charizopoulos, N.; Michas, S. Potential dam breach analysis and flood wave risk assessment using HEC-RAS and remote sensing data: A multicriteria approach. Water 2021, 13, 364. [CrossRef]

12. Psomiadis, E.; Soulis, K.X.; Zoka, M.; Dercas, N. Synergistic approach of remote sensing and GIS techniques for flash-flood monitoring and damage assessment in Thessaly Plain Area, Greece. Water 2019, 11, 448. [CrossRef]

13. Mouratidis, A.; Karadimou, G.; Ampatzidis, D. Extraction and Validation of Geomorphological Features from EU-DEM in the Vicinity of the Mygdonia Basin, Northern Greece. In IOP Conference Series: Earth and Environmental Science; IOP Publishing: Bristol, UK, 2017; Volume 95, p. 032009.

14. Garcia, G.; Grohmann, C. DEM-based geomorphological mapping and landforms characterization of a tropical karst environment in southeastern Brazil. J. S. Am. Earth Sci. 2019, 93, 14-22. [CrossRef]

15. González-Moradas, M.; Viveen, W. Evaluation of ASTER GDEM2, SRTMv3.0, ALOS AW3D30 and TanDEM-X DEMs for the Peruvian Andes against highly accurate GNSS ground control points and geomorphological-hydrological metrics. Remote Sens. Environ. 2020, 237, 111509. [CrossRef]

16. Hirt, C.; Filmer, M.S.; Featherstone, W.E. Comparison and Validation of the Recent Freely Available ASTER-GDEM Ver1, SRTM Ver4. 1 and GEODATA DEM-9S Ver3 Digital Elevation Models over Australia. Aust. J. Earth Sci. 2010, 57, 337-347. [CrossRef]

17. Satgé, F.; Bonnet, M.; Timouk, F.; Calmant, S.; Pillco, R.; Molina, J.; Lavado-Casimiro, W.; Arsen, A.; Crétaux, J.F.; Garnier, J. Accuracy Assessment of SRTM V4 and ASTER GDEM V2 Over the Altiplano Watershed using ICESat/GLAS Data. Int. J. Remote Sens. 2015, 36, 465-488. [CrossRef]

18. Elkadiri, R.; Manche, C.; Sultan, M.; Al-Dousari, A.; Uddin, S.; Chouinard, K.; Abotalib, A.Z. Development of a Coupled Spatiotemporal Algal Bloom Model for Coastal Areas: A Remote Sensing and Data Mining-Based Approach. IEEE J. Sel. Top. Appl. Earth Obs. Remote Sens. 2016, 9, 5159-5171. [CrossRef]

19. Polat, N.; Uysal, M.; Toprak, A.S. An investigation of DEM generation process based on LiDAR data filtering, decimation, and interpolation methods for an urban area. Measurement 2015, 75, 50-56. [CrossRef]

20. Abotalib, A.Z.; Sultan, M.; Elkadiri, R. Groundwater processes in Saharan Africa: Implications for landscape evolution in arid environments. Earth-Sci. Rev. 2016, 156, 108-136. [CrossRef]

21. Nikolakopoulos, K.G.; Choussiafis, C.; Karathanassi, V. Assessing the quality of DSM from ALOS optical and radar data for automatic drainage extraction. Earth Sci. Inform. 2015, 8, 293-307. [CrossRef] 
22. Farr, T.G.; Rosen, P.A.; Caro, E.; Crippen, R.; Duren, R.; Hensley, S.; Kobrick, M.; Paller, M.; Rodriguez, E.; Roth, L. The Shuttle Radar Topography Mission Reviews of Geophysics, Vol. 45. RG2004 2007, 10, 1-13.

23. El Bastawesy, M.; White, K.; Nasr, A. Integration of Remote Sensing and GIS for Modelling Flash Floods in Wadi Hudain Catchment, Egypt. Hydrol. Process. Int. J. 2009, 23, 1359-1368. [CrossRef]

24. Attwa, M.; El Bastawesy, M.; Ragab, D.; Othman, A.; Assaggaf, H.M.; Abotalib, A.Z. Towards an Integrated and Sustainable Water Resources Management in Structurally-Controlled Watersheds in Desert Environments using Geophysical and Remote Sensing Methods. Sustainability 2021, 13, 4004. [CrossRef]

25. Li, J.; Wong, D.W. Effects of DEM Sources on Hydrologic Applications. Comput. Environ. Urban Syst. 2010, 34, 251-261. [CrossRef]

26. Li, X.; Lin, J.; Zhao, W.; Wen, F. Approximate calculation of flash flood maximum inundation extent in small catchment with large elevation difference. J. Hydrol. 2020, 590, 125195. [CrossRef]

27. Mohamed, S.A. Development of a GIS-based alert system to mitigate flash flood impacts in Asyut governorate. Egypt. Natural Hazards 2021, 107, 1-25.

28. Nourani, V.; Asl, S.M.; Sorkhkolaee, M.K.; Sharghi, E. Effect of DEM Type and Resolution in Extraction of Hydro-Geomorphologic Parameters. In Recent Advances in Continuum Mechanics, Hydrology and Ecology; WSEAS: Athens, Greece, 2013; Volume 14, pp. 98-103.

29. Costache, R.; Bao Pham, Q.; Corodescu-Roșca, E.; Cîmpianu, C.; Hong, H.; Thi Thuy Linh, N.; Ming Fai, C.; Najah Ahmed, A.; Vojtek, M.; Muhammed Pandhiani, S.; et al. Using GIS, remote sensing, and machine learning to highlight the correlation between the land-use/land-cover changes and flash-flood potential. Remote Sens. 2020, 12, 1422. [CrossRef]

30. Ludwig, R.; Schneider, P. Validation of digital elevation models from SRTM X-SAR for applications in hydrologic modeling. ISPRS J. Photogramm. Remote Sens. 2006, 60, 339-358. [CrossRef]

31. Berry, P.A.M.; Garlick, J.D.; Smith, R.G. Near-global validation of the SRTM DEM using satellite radar altimetry. Remote Sens. Environ. 2007, 106, 17-27. [CrossRef]

32. Mouratidis, A.; Ampatzidis, D. European digital elevation model validation against extensive global navigation satellite systems data and comparison with SRTM DEM and ASTER GDEM in Central Macedonia (Greece). ISPRS Intern. J. Geo-Inf. $2019,8,108$. [CrossRef]

33. Barasa, B.N.; Perera, E.D.P. Analysis of land use change impacts on flash flood occurrences in the Sosiani River basin Kenya. Int. J. River Basin Manag. 2018, 16, 179-188. [CrossRef]

34. Sakran, S.; Said, S.M. Structural Setting and Kinematics of Nubian Fault System, SE Western Desert, Egypt: An Example of Multi-Reactivated Intraplate Strike-Slip Faults. J. Struct. Geol. 2018, 107, 93-108. [CrossRef]

35. Bosworth, W.; Stockli, D.F.; Helgeson, D.E. Integrated outcrop, 3D seismic, and geochronologic interpretation of Red Sea dikerelated deformation in the Western Desert, Egypt-The role of the 23 Ma Cairo "mini-plume". J. Afr. Earth Sci. 2015, 109, 107-119. [CrossRef]

36. Hegazy, D.; Abotalib, A.Z.; El-Bastaweesy, M.; El-Said, M.A.; Melegy, A.; Garamoon, H. Geo-Environmental Impacts of Hydrogeological Setting and Anthropogenic Activities on Water Quality in the Quaternary Aquifer Southeast of the Nile Delta, Egypt. J. Afr. Earth Sci. 2020, 172, 103947. [CrossRef]

37. Said, R. The Geological Evolution of the River Nile; Springer Science \& Business Media: Berlin, Germany, 2012.

38. Klitszch, E.; List, F.K.; Pohlmann, G. Geological Map of Egypt; 1:500,000; Conoco Coral: Cairo, Egypt, 1987 ; p. 24.

39. Maidment, D.R. GIS and Hydrologic Modeling. In Environmental Modeling with GIS; Goodchild, M.F., Parks, B.O., Eds.; Oxford University Press Inc.: New York, NY, USA, 1993; pp. 147-167.

40. Nicholson, S.E. Desert Hydrology. In Encyclopedia of Hydrology and Lakes. Encyclopedia of Earth Science; Springer: Dordrecht, The Netherlands, 1998; pp. 176-183.

41. Jenson, S.K.; Domingue, J.O. Extracting Topographic Structure from Digital Elevation Data for Geographic Information System Analysis. Photogramm. Eng. Remote Sens. 1988, 54, 1593-1600.

42. Ozulu, I.M.; Gökgöz, T. Examining the Stream Threshold Approaches used in Hydrologic Analysis. ISPRS Intern. J. Geo-Inf. 2018, 7, 201. [CrossRef]

43. Chang, N.B.; Guo, D.H. Urban flash flood monitoring, mapping and forecasting via a tailored sensor network system. In Proceedings of the IEEE International Conference on Networking, Sensing and Control, Lauderdale, FL, USA, 23-25 April 2006; pp. 757-761.

44. Mohtar, W.H.; Abdullah, J.; Maulud, K.N.; Muhammad, N.S. Urban flash flood index based on historical rainfall events. Sustain. Cities Soc. 2020, 56, 102088. [CrossRef]

45. McCauley, J.F.; Schaber, G.G.; Breed, C.S.; Grolier, M.J.; Haynes, C.V.; Issawi, B.; Elachi, C.; Blom, R. Subsurface valleys and geoarcheology of the eastern Sahara revealed by shuttle radar. Science 1982, 218, 1004-1020. [CrossRef] [PubMed]

46. Tribe, A. Automated Recognition of Valley Heads from Digital Elevation Models. Earth Surf. Process. Landforms 1991, 16, 33-49. [CrossRef]

47. Tarboton, D.G.; Bras, R.L.; Rodriguez-Iturbe, I. On the Extraction of Channel Networks from Digital Elevation Data. Hydrol. Process. 1991, 5, 81-100. [CrossRef]

48. Niyongabire, E.; Hassan, R.; Elhassan, E.; Mehdi, M. Use of Digital Elevation Model in a GIS for Flood Susceptibility Mapping: Case of Bujumbura City. In Proceedings of the 6th International Conference on Cartography and GIS, Albena, Bulgaria, 13 June 2016; pp. 241-248. 
49. Garbrecht, J.; Martz, L.W.; Starks, P. Automated Watershed Parameterization from Digital Landscapes: Capabilities and Limitations. In Proceedings of the Fourteenth Annual AGU Hydrology Days, Fort Collins, CO, USA, 5-8 April 1994; Morel-Seytoux, H.J., Ed.; Hydrology Days Publications: Atherton, CA, USA, 1994; pp. 123-134.

50. Wolock, D.M.; Price, C.V. Effects of Digital Elevation Model Map Scale and Data Resolution on a Topography-based Watershed Model. Water Resour. Res. 1994, 30, 3041-3052. [CrossRef] 